\title{
Kesalahan Berbahasa Pada Teks Berita Covid-19 Di Media Daring CNN Indonesia
}

\author{
Ana Farichatun Naschah, Dwi Rahmawati, Triasih \\ Institut Agama Islam Negeri Surakarta \\ triasih497@gmail.com
}

\begin{abstract}
Online news is the news that is widely accessed in this digital era, because it is faster, more accurate, and flexible. At the beginning of 2020, the whole world is facing the Corona or Covid-19 virus. In cyberspace itself, many sites have the Corona theme as their main news. However, it is not uncommon for language errors to be found in online news, both errors during the typing process, as well as pure errors from the personal error of the author who is not careful in using language rules. This study aims to determine how many types of language errors are in CNN Indonesia's online news about Covid-19 for the March 2020 period. This type of research is a qualitative descriptive study. Data collection techniques in this study used the observation and note technique. Data analysis techniques were carried out starting from the beginning in the form of collection, recording, and classification. Based on the results of this study, four areas of language error were found, namely: (1) spelling (writing italics), (2) morphology (affix me (N) and prefix meN-), (3) syntax (illogical sentences, and non-logical sentences. frugal), (4) diction (connotative meaning and non-standard words). With this research, so that in the future the news presented can provide knowledge to readers by writing well and correctly.
\end{abstract}

Keywords: Language error, Covid-19, CNN Indonesia

Abstrak. Berita daring merupakan berita yang banyak
diakses pada era digital ini, karena lebih cepat, akurat, dan
fleksibel. Pada awal tahun 2020 ini, seluruh dunia sedang
menghadapi virus Corona atau Covid-19. Di dunia maya
sendiri, banyak situs-situs yang mengangkat tema Corona
sebagai berita utamanya. Namun tak jarang ditemukan
kesalahan berbahasa pada berita daring, baik kesalahan
ketika proses pengetikan, maupun kesalahan murni dari
pribadi penulis yang kurang teliti dalam menggunakan
kaidah kebahasaan. Penelitian ini ditujukan untuk 
mengetahui seberapa banyak jenis kesalahan berbahasa pada berita daring CNN Indonesia tentang Covid-19 Periode Maret 2020. Jenis penelitian ini adalah penelitian deskriptif kualitatif. Teknik pengumpulan data dalam penelitian ini memakai teknik simak dan catat. Teknik analisis data dilakukan mulai dari awal berupa pengumpulan, pencatatan, dan klasifikasi. Berdasarkan hasil penelitian ini ditemukan empat bidang kesalahan berbahasa, yaitu: (1) ejaan (penulisan huruf miring), (2) morfologi (afiks me(N) dan Prefiks meN-), (3) sintaksis (kalimat tidak logis, dan kalimat tidak hemat), (4) diksi (makna konotatif dan kata tidak baku). Dengan adanya penelitian ini, agar kedepannya berita-berita yang disajikan dapat memberikan pengetahuan kepada pembaca dengan penulisan baik dan benar.

Kata Kunci: Kesalahan berbahasa, Covid-19, CNN Indonesia

\section{Pendahuluan}

Pesatnya perkembangan IPTEK di Indonesia saatt ini mengubah segala hal menjadi bersifat daring. Kelebihan daring (online) salah satunya bersifat efektif dan efisien yaitu suatu kebutuhan terhadap informasi mampu diakses dari mana saja dengan alat sederhana zaman ini yaitu handphone (HP), dan alat utama yang digunakan dalam membantu pekerjaan. Maksud dari efektif dan efisien adalah dengan bermodal gawai dan sambungan internet sudah bisa mengakses segala keperluan masyarakat sehari-hari. Seperti aplikasi transportasi ojek online, yang tidak hanya menawarkan untuk antar jemput penumpang saja, tetapi antar pesanan makanan, barang, pulsa, dan lain sebagainya. Selain aplikasi ojek online yang sangat mempermudah pekerjaan sehari-hari, ada juga buku online yang biasa dikenal dengan sebutan e-book. E-book bisa berupa buku pelajaran, novel, dan buku referensi lainnya. Begitu pula dengan penyajian berita, baik dalam bentuk e-paper maupun penayangan kembali di Youtube. Dalam persaingan di dunia industri 4.0, penyajian berita juga dipermudah melalui website, youtube, dan media social. Hal ini mempermudah masyarakat dalam menemukan suatu inforamsi yang dibutuhkan serta pembaca berita selalu mendapatkan berita terbaru dimana pun dan kapan pun.

Cable News Network (CNN) Indonesia merupakan stasiun televisi dan situs berita yang bekerja sama dengan beberapa pihak. Saluran ini 
pertama kali disiarkan pada Senin, 17 Agustus 2015. Saluran CNN Indonesia disiarkan menggunakan bahasa Indonesia dan berita yang disajikan mencakup berita lokal dan internasional dengan fokus pada berita umum, bisnis, olahraga, teknologi dan hiburan. Berbagai program disiarkan di saluran televisi selama 24 jam. Selain menyiarkan berita di televisi, CNN Indonesia juga menyediakan website dan youtube bagi masyarakat yang tidak bisa berada di depan layar televisi setiap saat. Situs website dan youtube yang mudah diakses kapan pun akan menguntungkan bagi masyarakat sehingga dapat menerima berita dengan cepat dan akurat tanpa harus menonton televisi.

Berbicara tentang stasiun televisi dan situs berita, akhir-akhir ini dunia pemberitaan sedang fokus menyorot tentang kasus Covid-19. Berita ini merupakan suguhan yang sedang hangat dan penting untuk memberikan edukasi serta informasi kepada masyarakat tentang kasus Covid-19 yang terjadi di Indonesia. CNN Indonesia turut menginformasikan berita lewat stasiun televisi dan situs berita daring. Pada tanggal, 2 Maret 2019 ditemukan kasus pertama di Indonesia yakni dua Warga Negara Indonesia (WNI) yang berdomisili di Depok diketahui positif mengidap virus SARS Cov-2. Kedua pengidap Covid-19 itu memiliki riwayat berinteraksi dengan WN Jepang yang lebih dulu menderita penyakit tersebut. Kedua WNI itu, ibu dan anaknya, tengah menjalani perawatan di ruang isolasi RSPI Dr Sulianti Saroso, Jakarta. Hal ini disampaikan secara langsung oleh Presiden Joko Widodo, Senin (2/3/2020), di Jakarta (Ratna Nuraini, 2020). Sejak saat itu terjadi penambahan pasien positif corona. Ranah berita baik di televisi maupun situs berita daring gempar menginformasikan berita terkait dengan kasus Covid-19. Sama halnya dengan CNN Indonesia yang selalu update informasi terbaru perkembangan Covid-19 di Indonesia sejak awal Maret 2020.

Penyampaian berita baik melalui televisi maupun situs berita tidak jauh dari penggunaan bahasa sebagai alat komunikasi penyampai informasi. Peran bahasa yang sesuai sangat diperlukan dalam penyajian berita agar dapat diterima oleh masyarakat. Bahasa menjadi salah satu aspek sarana alat komunikasi. Bahasa merupakan sebuah alat yang digunakan dalam berkomunikasi baik secara tulis maupun lisan yang 
dapat dipahami antara penutur dan mitra tuturnya (Almajid, 2019). Penggunaan bahasa pada surat kabar memiliki ciri khas tersendiri yaitu dalam penggunaan bahasanya yang lugas dan sistematika penulisan yang berpedoman kepada PUEBI (Pedoman Umum Ejaan Bahasa Indonesia) (Nisa, 2018). Tujuannya agar berita yang disajikan dapat memberikan pengetahuan kepada pembaca dengan penulisan yang baik dan benar. Akan tetapi, masih banyak terjadi kesalahan penulisan dalam berita di surat kabar baik yang berupa koran maupun website. Hal ini juga ditemukan pada berita yang disajikan di website CNN Indonesia yakni kesalahan penulisan ejaan, sintaksis, dan morfologi.

Kesalahan berbahasa yang banyak terjadi dimasyarakat, antara lain, adanya perkembangan dan penggunaan bahasa Indonesia yang menuju ke penggunaan bahasa standar. Dalam kaitan antara kemauan dan kesadaran menurut Arifin dalam (Kurniasari et al., 2018) bahwa dalam pemakai bahasa sudah sepatutnya dapat menggunakan kosakata yang dikuasainya dengan tepat. Penggunaan kosakata yang tepat akan berpengaruh kepada tulisan yang mudah dibaca. Betapa pentingnya pemilihan kosakata dilakukan dengan cermat agar kalimat yang disusun dapat dipahami pembaca atau pendengarnya dengan baik. Fernandez \& Mukhlish dalam (Permatasari et al., 2019) menyebutkan yang termasuk dalam kesalahan ejaan adalah kesalahan dalam pemakaian huruf, penulisan kata, pemakaian tanda baca, dan ejaan kombinasi.

Selain pada kesalahan ejaan, adanya kesalahan morfologi dapat dilihat dari proses pembubuhan afiks dan pengulangan-pengulangan kata yang tidak perlu. Kata merupakan satuan gramatikal terkecil dan bersifat bebas. Kata yang di belakang (untuk preposisi), kata yang berada di depannya (untuk posposisi), dan dengan kata-kata yang dirangkainya (untuk konjungsi) (Chaer, 2018). Proses morfologi disebut dengan proses pembentukkan beberapa kata dari satuan lain yang merupakan bentuk dasar. Ada tiga bentuk proses morfologi, yakni proses pembubuhan afiks (afiksasi), proses pengulangan (reduplikasi), dan proses pemajemukan (pemajemukan).

Selanjutnya kesalahan sintaksis yang berhubungan dengan makna yang harus disesuaikan. Kesalahan tataran sintaksis adalah kesalahan yang dapat ditemukan dan terjadi pada tataran frasa, klausa, 
kalimat dan wacana. M. Ramlan dalam (Herniti, 2017) menjelaskan bahwa sintaksis merupakan cabang ilmu bahasa dengan fokus mengkaji tentang seluk beluk wacana, kalimat, klausa, dan frasa. Pentingnya memperhatikan tataran sintaksis agar tidak menciptakan kalimat tidak logis. Hal ini akan menyulitkan pembaca dalam memahami makna tulisan dalam berita.

Adanya kesalahan pada pemilihan diksi atau kosakata sering ditemukan dalam penulisan teks berita.. Menurut Sumartono dalam (Fajriyani et al., 2020) diksi merupakan kata yang digunakan untuk menyatakan perasaan dan pikiran yang dijelaskan dalam pola kalimat dengan tepat. Penggunaan diksi yang tepat untuk disampaikan baik dalam bentuk tulis maupun lisan akan berpengaruh pada pemahaman yang diterima pembaca. Kalimat dalam berita harus bersifat denotasi agar tidak menimbulkan pemahaman yang berbeda dengan penulis.

Penelitian terkait analisis kesalahan berbahasa pada berita dalam media juga pernah dilakukan oleh (Nisa, 2018) Analisis Kesalahan Berbahasa pada Berita dalam Media Surat Kabar Sinar Indonesia Baru. Pada penelitian tersebut terdapat kesalahan berbahasa pada bidang ejaan, morfologi, semantik dan sintaksis pada surat kabar Sinar Indonesia Baru (SIB) edisi Desember 2017. Persamaan penelitian ini dengan penelitian sebelumnya yakni pada objek penelitian yang berupa analisis kesalahan berbahasa pada berita tertulis. Penelitian ini merupakan penelitian yang mengandung kebaruan, karena mengangkat tema yang sedang hangat dibicarakan dan dilakukan dalam situs berita terbaru yaitu CNN Indonesia yang menyajikan dalam bentuk siaran televisi, website berita, dan video di youtube. CNN Indonesia berbeda dengan e-papper, CNN merupakan media memuat berita daring yang dikelompokkan sesuai minat pembaca. Objek penelitian ini adalah untuk mengetahui bentuk kesalahan berbahasa pada berita daring CNN Indonesia tentang Covid-19 periode Maret 2020.

Penelitian ini menggunakan metode deskriptif kualitatif, yaitu mendeskripsikan data-data yang diperoleh dari hasil penelitian. Pada penelitian kualitatif kegiatan penyediaan data merupakan kegiatan yang berlangsung secara bersamaan dengan kegiatan analisis data. Fokus analisis kualitatif yaitu pada penunjukan makna, deskripsi, penjernihan, 
dan penempatan data pada konteksnya masing-masing dan sering kali melukiskannya dalam bentuk kata-kata daripada angka-angka (Mahsun, 2005). Teknik pengumpulan data dalam penelitian ini memakai teknik simak dan catat kemudian diklasifikasikan menurut jenis objek penelitian. Teknik analisis data dilakukan mulai dari awal berupa pengumpulan, pencatatan, dan klasifikasi. Data tersebut kemudian dianalisis sehingga dapat diperoleh makna kata secara tepat. Kegiatan setelah itu adalah membuat kesimpulan yang didapat dari hasil analisis dan verifikasi agar lebih terfokus. Menurut Sudaryanto dalam (Hariyani, 2013) teknik catat merupakan teknik penyediaan data yang dilakukan dengan cara pencatatan pada data.

Dengan adanya penelitian ini diharapkan dapat mengklasifikasikan berbagai jenis kesalahan berbahasa pada berita daring CNN Indonesia tentang Covid-19 periode Maret 2020, pada bidang ejaan, morfologi, sintaksis dan diksi, serta mengetahui analisis pembenaran pada kesalahan berbahasa berita daring yang ditulis oleh penulis.

\section{Pembahasan}

Berdasarkan hasil penelitian mengenai kesalahan berbahasa pada berita daring CNN Indonesia tentang Covid-19 periode Maret 2020 menunjukkan bahwasannya terdapat empat tataran kesalahan berbahasa dengan jumlah 12 temuan data penelitian.

\section{Kesalahan dalam Bidang Ejaan}

Ejaan merupakan aturan tulis-menulis dalam menggambarkan suatu bahasa yang berhubungan dengan penulisan huruf, kata, unsur serapan, dan penggunaan tanda baca (Qhadafi, 2018). Pada situs berita CNN Indonesia tentang Covid-19 periode Maret 2020 terdapat kesalahan berbahasa bidang ejaan, antara lain:

1. "Sebagai contoh, dancer dan aktor Vietnam, Quang Dang yang mengajak orang mencuci tangan lewat gerakan tari.

Video pun meraup lebih dari sejuta penonton di TikTok dan lebih dari 25 ribu penonton di Instagram.

Virus menyebar melalui droplet (tetesan) cairan. “ 
Dari kutipan berita yang ditulis oleh CNN Indonesia dengan judul berita "Ramai- ramai Cuci Tangan Demi Tangkal Virus Corona" edisi Sabtu, 7 Maret 2020 tersebut mengalami kesalahan ejaan pada penggunaan kata asing yang seharusnya ditandai dengan cetak miring atau dipertebal pada kata dancer, TikTok, Instagram, dan droplet. (Qhadafi, 2018) juga menerangkan bahwa huruf miring dalam cetakan dipakai untuk menuliskan kata nama ilmiah atau ungkapan asing kecuali yang telah disesuaikan ejaannya.

2. Pada judul berita CNN Indonesia "Update Corona 27 Maret: 1.046 Kasus, 87 Meninggal, 46 Sembuh" edisi Jumat, 27 maret 2020 terjadi kesalahan ejaan yaitu penggunaan kata asing yang seharusnya ditandai dengan cetak miring atau dipertebal pada kata update.

3. "Pemerintah telah berulang kali mengampanyekan kampanye sosial distancing dan beraktivitas. Selain itu, Yuri juga mengimbau masyarakat untuk tetap produktif selama tinggal di rumah, tak lupa untuk menerapkan physical distancing dan mengonsumsi makanan bergizi."

Dari kutipan berita CNN Indonesia dengan judul "Update corona 28 Maret : 1.155 kasus, 102 meninggal, 59 sembuh" edisi Sabtu, 28 Maret 2020 tersebut mengalami kesalahan ejaan pada penggunaan kata asing yang seharusnya ditandai dengan cetak miring atau dipertebal pada kata sosial distancing dan physical distancing.

4. "Ia menjelaskan ruang pemeriksaan antara penyidik dengan saksi atau tersangka dipisahkan dinding yang transparan. Selain itu, katanya, juga akan ada hand sanitizer di ruang pemeriksaan."

Dari kutipan berita CNN Indonesia dengan judul "KPK Ubah Prosedur Pemeriksaan Saksi Demi Cegah Corona” edisi Rabu, 25 Maret 2020 tersebut mengalami kesalahan ejaan pada penggunaan kata asing yang seharusnya ditandai dengan cetak miring atau dipertebal pada kata hand sanitizer.

5. "Nantinya Tim Satgas akan mengambil langkah tegas untuk mendisiplinkan warga agar menaati himbauan pemerintah dalam melakukan social distancing." 
dari kutipan berita CNN Indonesia dengan judul "Siaga Corona, Papua Tutup Akses Penerbangan dan Pelayaran" edisi Selasa, 24 Maret 2020 tersebut mengalami kesalahan ejaan pada penggunaan kata asing yang seharusnya ditandai dengan cetak miring atau dipertebal pada kata social distancing.

6. "Tes yang dilakukan berupa pengambilan sampel darah (rapid test), bukan pengambilan sampel lendir hidung atau tenggorokan (Polymerase Chain Reaction/PCR)."

Dari kutipan berita CNN Indonesia dengan judul "Semua Anggota DPR dan Keluarga Jalani Tes Corona" edisi Senin, 23 Maret 2020 tersebut mengalami kesalahan ejaan pada penggunaan kata asing yang seharusnya ditandai dengan cetak miring atau dipertebal pada kata (Polymerase Chain Reaction/PCR).

\section{Kesalahan dalam Bidang Morfologi}

Dalam mempelajari bahasa sebagai alat komunikasi seseorang dalam kehidupan sehari-hari akan berkaitan erat dengan morfologi. Morfologi merupakan cabang ilmu bahasa yang fokus mempelajari struktur bahasa yang mencakup kata dan bagian kata, yaitu morfem (Priyono, 2012). Pada situs berita CNN Indonesia tentang Covid-19 Periode Maret 2020 terdapat kesalahan berbahasa bidang morfologi, antara lain:

1. "Dia pun menantang netizen untuk turut menari sekaligus mengkampayekan kebiasaan cuci tangan guna mencegah infeksi virus corona."

Dari kutipan berita CNN Indonesia dengan judul "Ramai-ramai Cuci Tangan Demi Tangkal Virus Corona” edisi Sabtu, 07 Maret 2020 tersebut mengalami kesalahan morfologi pada penulisan "mengkampanyekan" dari kata dasar "kampanye" yang artinya gerakan serentak untuk melawan, mengadakan aksi. Kemudian mendapatkan afiks me(N)-kan yang menjadi mengampanyekan dan luluhnya fonem /k/ dalam kata "kampanye".

2. Pada judul berita CNN Indonesia "KPK Ubah Prosedur Pemeriksaan Saksi Demi Cegah Corona” edisi Rabu, 25 Maret 2020 tersebut terjadi kesalahan berbahasa di bidang morfolgi bagian Prefiks. sebaiknya 
kata "Ubah" ditambah Prefiks (meN-), sehingga menjadi “ mengubah."

\section{Kesalahan dalam Bidang Sintaksis}

Kesalahan sintaksis merupakan penyimpangan pada struktur frasa, klausa, atau kalimat, serta ketidaktepatan pemakaian partikel. Analisis kesalahan dalam bidang sintaksis atau tata kalimat meliputi urutan kata, kepaduan, susunan frase, kepaduan kalimat, dan logika kalimat (Wardani, 2016). Pada situs berita CNN Indonesia tentang Covid-19 Periode Maret 2020 terdapat kesalahan berbahasa bidang sintaksis, antara lain:

1. "Seperti diketahui, dalam beberapa terahir jumlah korban positif corona naik signifikan."

Dari kutipan berita CNN Indonesia dengan judul berita "Update corona 28 maret : 1.55 kasus, 102 meninggal, 59 sembuh" edisi Sabtu, 28 Maret 2020 tersebut terjadi kesalahan pada bidang sintaksis, yaitu kalimat tidak logis. Kalimat tidak logis adalah kalimat yang maknanya tidak dapat diterima akal sehat. Seharusnya setelah kata "beberapa" diberi keterangan waktu agar kalimat menjadi logis dan bisa dipahami oleh pembaca berita. kalimat logis adalah kalimat yang maknanya dapat diterima oleh akal sehat. Sebaliknya, kalimat dikatakan tidak logis atau tidak memenuhi logika kalimat manakala kalimat itu tidak dapat diterima oleh pemakai bahasa yang bersangkutan (Puspitasari, 2016).

2. "Pemerintah telah berulang kali mengampanyekan kampanye social distancing dan beraktivitas."

Dari kutipan berita CNN Indonesia dengan judul berita "Update corona 28 maret : 1.55 kasus, 102 meninggal, 59 sembuh" edisi Sabtu, 28 Maret 2020 tersebut terjadi kesalahan pada bidang sintaksis, yaitu kalimat tidak hemat, karena menggunakan kata yang maknanya sama. Kalimat yang tidak hemat adalah kalimat yang menggunakan dua bentuk kata yang maknanya sama dalam satu kalimat. Menulis sebuah kalimat yang baik maka harus memenuhi syarat sebagai kalimat yang efektif dan mudah dipahami oleh pembaca (Giyanti et al., 2019). Namun sering dijumpai pemakaian kata-kata yang 
mengandung makna yang sama digunakan sekaligus dalam sebuah kalimat yang menyebabkan kalimat tersebut tidak hemat atau mubazir.

\section{Kesalahan dalam Bidang Diksi}

Diksi adalah pilihan atau penggunaan kata. Kesalahan diksi merupakan kesalahan dalam pemilihan atau penggunaan kata. Dalam menulis, perlu memperhatikan pemilihan kosakata yang tepat dan sesuai. Ketepatan yang berarti kata yang dipilih dapat menyampaikan gagasan sebagaimana yang dikehendaki penulis agar tidak terjadi salah paham dengan pembaca. Sedangkan kesesuaian berarti kecocokan kata yang kita pilih dengan situasi, konteks dan sasaran (Hidayatullah, 2018). Pada situs berita CNN Indonesia tentang Covid-19 Periode Maret 2020 terdapat kesalahan berbahasa bidang diksi, antara lain:

1. "Yuri melanjutkan kasus kematian akibat Covid-19 hingga saat ini mencapai 87 orang."

Dari kutipan berita CNN Indonesia dengan judul berita "Update Corona 27 Maret: 1.046 Kasus, 87 Meninggal, 46 Sembuh" edisi Jumat, 27 Maret 2020 tersebut terjadi kesalahan pada bidang diksi yaitu mengandung makna konotatif. Makna konotatif adalah kalimat yang memiliki arti bukan makna sebenarnya atau kalimat yang bisa menimbulkan makna baru. Makna konotatif adalah suatu jenis kata yang memiliki arti bukan sebenarnya (Reskian, 2018). Kata "melanjutkan" pada kalimat tersebut termasuk tidak tepat, seharusnya kata tersebut diganti dengan kata "menegaskan" agar ketika berita tersebut dibaca tidak menimbulkan salah paham pada pembaca.

2. "Nantinya Tim Satgas akan mengambil langkah tegas untuk mendisiplinkan warga agar menaati himbauan pemerintah dalam melakukan social distancing."

Dari kutipan berita CNN Indonesia dengan judul berita "Siaga Corona, Papua Tutup Akses Penerbangan dan Pelayaran" edisi Selasa, 24 Maret 2020 tersebut terjadi kesalahan pada bidang diksi. Kata "himbauan" merupakan bentuk tidak baku dari "imbauan".

\section{Kesimpulan}


Berdasarkan hasil temuan data mengenai analisis kesalahan berbahasa pada berita daring CNN Indonesia tentang Covid-19 periode Maret 2020 dapat disimpulkan bahwa jumlah kesalahan dalam berita daring CNN Indonesia Covid-19 periode Maret 2020 menunjukan bahwasannya terdapat empat tataran kesalahan berbahasa dengan jumlah 12 temuan data penelitian, yaitu kesalahan pada tataran ejaan, sintaksis, dan kesalahan pada tataran diksi. Dari keempat kesalahan berbahasa tersebut yang paling banyak terjadi yaitu kesalahan berbahasa pada tataran ejaan mengenai kesalahan penulisan huruf miring.

\section{Daftar Pustaka}

Almajid, M. R. (2019). Tindak Verbal Abuse dalam Permainan Mobile Legend di Indonesia: Kajian Sosiolinguistik. Estetik, 2(2), 171182.

Chaer, A. (2018). Linguistik Umum (Edisi Revi). Jakarta: Rineka Cipta.

Fajriyani, N., Ridho, M. R., \& Laili, Q. (2020). Analisis Kesalahan Berbahasa di Bidang Diksi dalam Buku Panduan UPT Perpustakaan IAIN Surakarta Edisi 2018. Humaniora, 21(1), 5568.

Giyanti, Afifah, R. N., \& Wulandari, R. A. D. (2019). Analisis Kesalahan Berbahasa Bidang Sintaksis Buku Teks Bahasa Indonesia Kelas VIII Kurikulum 2013 Edisi Revisi 2017. Wacana: Jurnal Bahasa, Seni, Dan Pengajaran., 3(1), 28-34. https://doi.org/10.21009/10.21009/aksis.010102

Hariyani, E. E. (2013). Analisis Kesalahan Berbahasa Bidang Morfologi pada Surat Kabar Harian Jateng Pos Edisi Januari 2013. Universitas Muhammadiyah Surakarta.

Herniti, E. (2017). Kesalahan Berbahasa Indonesia Tulis pada Mahasiswa Thailand (Studi Atas Pembelajar BIPA di PPB UIN Sunan Kalijaga). THAQÃFIYYÃT, 18(1), 1-18.

Hidayatullah, A. (2018). Analisis Kesalahan Diksi pada Karangan Siswa Kelas IX SMP Islam Daar EL-Arqam Tangerang. El-Banar, 01, 4150 .

Kurniasari, N., Andrianti, V., \& Isnaini, H. (2018). Analisis Kesalahan Ejaan pada Salah Satu Judul Berita “ Isu TKA Digoreng Menjelang 
Pilpres " pada Surat Kabar Tribun Jabar Edisi 25 April 2018. Parole (Jurnal Pendidikan Bahasa Dan Sastra Indonesia), 1(April), 527-534.

Mahsun. (2005). Metode Penelitian Bahasa: Tahapan Strategi, Metode, dan Tekniknya. Jakarta: RajaGrafindo Persada.

Nisa, K. (2018). Analisis Kesalahan Berbahasa pada Berita dalam Media Surat Kabar Sinar Indonesia Baru Khairun Nisa Universitas Asahan Pendahuluan. Jurnal Bindo Sastra 2, 2, 218-224.

Permatasari, N. E., Khasanah, I. M., \& Putri, N. A. M. (2019). Kesalahan Berbahasa dalam Majalah Pandawa IAIN Surakarta Edisi 2018 pada Tataran Ejaan dan Sintaksis. Diglosia, 2(2), 103-114.

Priyono, Y. (2012). Analisis Kesalahan Berbahasa Bidang Morfologi pada Mading di Universitas Muhammadiyah Surakarta. Universitas Muhammadiyah Surakarta.

Puspitasari, D. F. (2016). Analisis Kesalahan Bidang Sintaksis pada Buku Teks Pelajaran Bahasa dan Sastra Indonesia untuk SMA dan MA Kelas X. In Universitas Muhammadiyah Surakarta (Vol. 53). Universitas Muhammadiyah Surakarta.

Qhadafi, M. R. (2018). Analisis Kesalahan Penulisan Ejaan yang Disempurnakan dalam Teks Negosiasi Siswa SMA Negeri 3 Palu. Jurnal Bahasa Dan Sastra, 3.

Ratna Nuraini. (2020). Kasus Covid-19 Pertama, Masyarakat Jangan Panik. Indonesia.Go.Id. https://indonesia.go.id/narasi/indonesiadalam-angka/ekonomi/kasus-covid-19-pertama-masyarakatjangan-panik

Reskian, A. (2018). Analisis Penggunaan Diksi pada Karangan Narasi di Kelas X IPS II SMA Negeri 1 Palu. Jurnal Bahasa Dan Sastra, 3(2). http://jurnal.untad.ac.id/jurnal/index.php/BDS/article/downloa d/9941/7903

Wardani, K. (2016). Analisis Kesalahan Berbahasa pada Bidang Sintaksis dalam Karangan Deskripsi Siswa Kelas X SMK Pelita Bangsa Boyolali. Universitas Muhammadiyah Surakarta. 